\title{
Sejrskode, økonomi og politik som begrundelse for sundhedsfare og regelbrud \\ - doping-historie og doping i DDR
}

Af Giselher Spitzer

Doping har en historie - og denne historie er rekonstruerbar. Dette fremgår af den sportvidenskabelige redegørelse for den til dels deprimerende fortid i DDR. Denne erkendelse muntrer imidlertid op: Kun det benævnelige, rekonstruktionen af den biokemiske manipulation med menneskers opståen og uddifferentiering gennem videnskabelig erkendelse, skaber sikker orientering om fortiden. DDR-doping og -sportssystem, pro- og contra-doping har derfor på samme måde som den tyske historikerstrid om forståelsen af sport under nationalsocialismen ${ }^{1}$ særlig betydning. Bekendelsen til normative ansatser (som Frankfurterskolens) tillader samtidig også værdidomme ${ }^{2}$ og hjælper dermed til ikke at gentage en gang begåede fejl. I bedste fald lykkes det sågar at korrigere strukturdefekter. Samtidshistorie som kritisk socialvidenskab har her en udtalt oplysende funktion og kan samtidig i særlig grad være handlingsorienteret: Dens resultater kan bruges i praktisk handling. ${ }^{3}$

En »appetizer « for en sådan tilgang: Hvor nyttig en sådan kritisk aktivitet er, viser det epokedannende (fordi det i første omgang var upopulært) omsving i fransk anti-doping-praksis under Tour de France i 1998. Trods nationalt uforandret (!) retssituation kom det i Republikken Frankrig ganske overraskende til en »Zero-Tolerance«-politik. Denne var ikke blot bestemt af europæisk harmonisering, men går i al væsentlighed tilbage til påvirkningen af kritisk litteratur i Frankrig og indflydelsen af beviste fakta om DDR-doping. ${ }^{4}$

Noget lignende gør sig gældende for Vesttyskland. Der blev den gennemgribende forandring $\mathrm{i}$ den offentlige mening fremkaldt både gennem opklarende littera$\operatorname{tur}^{5}$ og retssager pga. legemsbeskadigelse med doping-midler i DDR, samt gennem den medievirksomme bearbejdelse af de sundhedsmæssige følger af DDR-dopingen. Bemærkelsesværdigt er i denne forbindelse, at dette skete, mens dele af 1960'ernes og 1970'ernes gamle funktionær- og sportsvidenskabseliters opfattelser, der kan betegnes som virkelig vedholdende, levede videre. Således fordrede en forfatter, som lige fra dets grundlæggelse gav det vesttyske Deutscher Sportbund (DSB)-tidsskrift »Leistungssport « dets profil, at man af rets- og fairnessmæssige årsager ophørte med alle anti-doping-træningskontroller. ${ }^{6}$ I modsætning til de konspirative strukturer i DDR blev sådanne strategiske debatter i Vesttyskland principielt ført i offentlighedens lys, fordi pressen traditionelt udmærker sig ved en stor sensibilitet i dette spørgsmål. Slutteligt skal der 
henvises til den »substitutionsdebat « om f.eks. anabole steroider, som blev initieret af en tysk sportsmediciner. Debatten blev genoplivet $\mathrm{i}$ anledning af den tidligere cykelrytter og dopingpraktiker Dieter Thuraus ytringer i Frankfurter Allgemeine Zeitung den 9. juni 1999, som vel blev misforstået som opfordring til frigivelse af doping: Thuraus korrektion, at han på ingen måde $\emptyset$ nskede en frigivelse, fulgte kun to dage senere ${ }^{7}$ og frembragte poliske smil hos mange iagttagere af medicindiskursen.

Også indflydelsen fra de sportsjournalister, der var landsdækkende beskæftiget, viser sig eksemplarisk i denne demokratisk forfattede stat med et autonomt, føderalt sportssystem. Når man ser tilbage, iagttog de på dette område en gatekeeper-funktion, der på en god måde mindede om »cetero censeo «. Havde de svigtet, ville en doping-bekæmpelse være blevet glemt i det tiltagende doping-eftergivende klima i 1970 'erne. Modparten var her især den underskudsrolle, som den del af den vesttyske sportsmedicin, der var stærkt efterspurgt af foreningsorganiseret sport, spillede. ${ }^{8}$ Fjernsynsalderens elitesport var sådan set indtil et stykke ind i 1980'erne fejlagtigt blevet fortolket og fremstillet som et segment for granselos vakst. Den organiserede sport havde i den forbindelse tematiseret anabolika-dopingens rolle relativt lidt og havde haft en tendens til at fremstille den som harmløs, hvad Karl-Heinrich Bette og Uwe Schimanks sociologiske analyser overbevisende har påvist. ${ }^{9}$

Med benævnelse af den fortjeneste, som de kritiske analyser havde, der blev foretaget af dem, som normativt forstod sig selv som dopingens modkrafter, foregribes altså konklusionen. Efter denne »lovtale« skal dette afsnits røde tråd skitseres. Den moderne sports overbudsprincip var forudsætning for den biokemiske manipulation.
Uden henvisning til den omfattende, foreliggende litteratur, som i grunden analyserer drivkræfter for den moderne sportsudvikling, der ligner hinanden, kan det fastlægges, at den moderne »sport « $\mathrm{i}$ slutningen af det 19. århundrede startede sit sejrstog, at konceptet imidlertid i Tyskland kolliderede med den egalitære, pædagogisk og politisk funderede ældre og traditionelle »Turnen«. Dér fokuseredes på formningen af kroppen og opbygningen af en $\varnothing$ velse, men ikke på en abstrakt præstation. Den »engelske« sport satsede derimod på den sportslige sammenligning, $i k$ ke på en bevagelses kvalitet: Ved siden af den direkte sammenligning i kappestriden indførtes snart overvindelsen af modstanderen gennem den abstrakte, målte og offentliggjorte »rekord « eller sågar løb udelukkende »mod uret «. Pga. den angelsaksiske tradition var chancelighed en tilstrækkelig og amatørstatus en nødvendig forudsætning i den forbindelse, selvom der ofte nok klagedes over afvigende forhold. Sporten vandt hurtigt tilhængere på det foreningsorganiserede område, derefter hos tilskuerne og derigennem i massemedierne. Industrialiseringens strukturkendetegn såsom rationalitet, teknikalisering og ikke mindst $\varnothing$ konomiske kriterier (udviklingen af professionssporten) forbandt $\mathrm{i}$ den forbindelse sport og leg med samfundsmæssige moderniseringsprocesser. Præstationssammenligninger og rekordlister fordrede desuden et nøjagtigt regelsæt og normering af sportsudstyr og -anlæg, hvilket kun var muligt gennem forordninger og institutionsdannelser. Følgen var nationale og internationale forbund, senere også tiltagende professionalisering og kommercialisering. Særligt efter 1. Verdenskrig kunne man betragte en generel forbedring i præstationer som følge af indføring af en systematisk træning og udvik- 
lingen af sportsvidenskaben og sportsmedicinen. Ud fra denne erfaring så man i første omgang ingen grænser for en fremtidig forbedring, hvilket imidlertid blev forstået som forudsætning for opretholdelsen af en disciplins attraktivitet. Ved de store konkurrencer og OL blev der kæmpet om de individuelle placeringer, men også om sportsnationernes placering. Her kunne man iagttage forskellige punkter, ved hvilke man kunne tænke sig manipulation med den virkelige præstationsfærdighed, sådan som det tidlige tilfælde med marathonløberen Pietri viser: Han (eller rettere: hans læge!) anvendte ikke forbudte præparater $\ldots{ }^{10}$ Den ene mulighed var bestikkelse af dommeren og de sportslige konkurrenter, hvilket var dyrt og krævede medsammensvorne. Den anden mulighed var usynlig manipulation med atletens fysik og psyke - vha. doping-midler. Allerede her kan det ses at kvinder og piger i lang tid ikke lå under for denne logik. ${ }^{11}$

På dette punkt skal - i en efter min mening tilladelige forgrovelse - indvarsles en reduktion til to motiver. Det første, oprindelige og vedvarende aspekt kan vi nærme os gennem en tysk talemåde fra 1920'erne: »Betrogen wird viel auf dem Planeten doch nicht so viel wie unter Leichtatleten « (der snydes meget på planeten - men ikke så meget som blandt atletikudøvere). ${ }^{12}$ På dette tidspunkt mentes hverken sporten udelukkende i Tyskland eller atletikken som den eneste sportsgren med bedrageriske tendenser i præstationssammenlignende praksis. Det, der mentes, var »afvigelse«, altså bedrageriske sportsudøveres eller dommeres subegale, eller i det mindste normafvigende, holdning. Denne del er følgelig ikke kronologisk anlagt og refererende, men snarere problemorienteret. Aktuelle systemer kan man f.eks. læse om i forbindelse med cykelsport, ${ }^{13}$ eller i det nye standardværk om svømmesport, der går ud fra DDR-strukturene, men også spørger til, hvad der aktuelt sker på doping-området i denne sportsgren. ${ }^{14} \mathrm{Hvad}$ er forudsætningerne for manipulationer med mennesket? Hertil hører et udviklet konkurrencesystem, med hvilket en vinder i sporten fastlægges ved hjælp af delvist automatiske metoder, der ikke kan efterprøves emotionelt: Forspringet på en tusindedel sekund som paradigme for moderne præstationer kan ikke længere vurderes af tilskueren uden inddragelse af maskiner og specialiserede instanser, og indflydelsen er taget fra atleterne. I denne situation sker snyderiet ikke tilfældigt: Den, der snyder, vil jo ændre konkurrencens resultat til sin egen fordel, uden i sportslig sammenhæng overhovedet at kunne opnå den $\emptyset$ nskede placering uden manipulation. Som motiver for den doping, som den enkelte selv er ansvarlig for, optræder personligt befindende eller tilstrækkeligt høj materiel tillokkelse. Doping følger derfor professionel sport og fanger større persongrupper i den nuværende kommercialiserede periode, som $\varnothing$ jensynligt endnu ikke står foran sin afslutning. Samtidig tiltager hyppigheden af konkurrencer, ved hvilke der skal gives prøver på atletens kunnen, og hvor der gives lejlighed til gennem atleten og hans evner at maksimere udbyttet.

Snyderi - det skal her tilføjes - eksisterer i betragtning af perfektionerede målemetoder også $u d$ fra politiske motiver. Tilbage i den græske antik havde vinderen $h \varnothing j$ rang som repræsentant for sin polis og forhøjede dennes præstationsevne, således forestillede man sig det i den græske verden. I moderne sport og i nationalstaternes tidsalder var det ikke spor anderledes. Også det omvendte er tilfældet: For at forhindre en forhadt befolkningsgruppe $i$ at få højere status, blev en, som det fremgik af 
målfotoet, klar vinder for trekvart århundrede siden i Helsinki degraderet til nummer fire. Det drejede sig om sprinteren Tokazier. Årsagen til fradømmelsen kan kun være, at han var af jødisk tro og startede i den finske »Makkabis« trikot: Man skrev netop året 1938, store dele af finsk sport var antisemitisk indstillet, og udsendinge fra det nazistiske »Großdeutschland « var til stede ved denne »racemæssigt mindreværdige « atlets sejr. ${ }^{15}$ De politiske motiver har beviseligt, i det mindste i det 20. århundrede, begunstiget alle typer snyderi inklusive doping. Instrumentariet for analysen kan idealtypisk beskrives som følger:

- »Afvigelse « gennem biokemiske manipulationer med mennesket i konkurrencesportens udviklede system er som bedrageriske atleter og deres omgivelsers subegale adfærd et bedrag, der skal ændre konkurrencens udfald. Manipulationen sker ud fra personlige, materielle eller politiske motiver, hvorved det negative, såsom sundhedsfare og regelbrud, fortranges. Manipulation uden den aktives vidende er derved ultima ratio, som strider mod den humant grundlæggende etos i samarbejdet mellem sportsudøver og leder.

\section{Historiske eksempler på doping-praktikker og-diskurser}

Kan man allerede nu med uomstødelige fakta opridse en forskningsbaseret almen doping-historie? Svaret er nej. Der foreligger mange ansatser, der grundet pladsen ikke tilnærmelsesvis kan sammenfattes her, og som delvist modsiger hinanden. »Lange linjer « aftegner sig dog og vil blive understøttet af relevant litteratur. Ikkenævnte forfattere må tilgive mig, hvis kun enkelte tyngdepunkter benævnes. Brugen af litteratur skylder, at denne teksts forfatter er specialiseret i DDR-sport, hvor han, idet han byggede på undersøgelser og kilder fra Brigitte Berendonk og Werner Franke, vidtgående kunne beskrive og forklare systemets opståen og forandring. ${ }^{16}$ Forklarende og præventive modeller kan ikke behandles her.

Barrie Houlihans udmærkede datasamling ordner forløbene. Nogle udsnit om »prominente « doping-midler tydeligg $\varnothing r$ misbrugets forskellige rytmer ${ }^{17}$ og sættes derpå over for historiske unders $\emptyset$ gelsesresultater for præparater og sportgrene samt betingelserne for den pågældende dopingforms opståen:

Figur 1.

\begin{tabular}{|l|l|l|l|}
\hline Stoffets navn & Opdagelse & $\begin{array}{l}\text { Forste gang } \\
\text { benyttet } i \text { sport }\end{array}$ & $\begin{array}{l}\text { Primart benyttet } \\
\text { i perioden }\end{array}$ \\
\hline Koffein & før 1800 & starten af 19. årh. & siden 1970 \\
Kokain & før 1700 & slutningen af 19. årh. & siden 1960, stigende \\
Amfetamin & 1920 & 1940 & 1950 til slutningen af 1970'erne \\
Anabolika & 1930 & 1950 & $1960-1990$ \\
Ephedrin & 1940 & 1970 & siden 1970 \\
Egenbloddoping & 1970 & 1970 & $(?)$ \\
Erythropoitin & 1985 & slutningen af 1980'erne & siden 1990, stigende \\
Væksthormon & 1985 & slutningen af 1980'erne & $(?)$ \\
\hline
\end{tabular}


Lad os begynde: I sportshistorien kan man allerede tidligt påvise anvendelsen af opstramningsmidler, som i første omgang stammede fra naturlægekunsten (f.eks. digitalis, galnebær), senere fra moderne stimulanser (pga. de allopatiske præparaters bedre doserbarhed og praktikabilitet). Disse stoffer, der fra vore dages perspektiv kan betegnes som »klassiske doping-midler«, var f.eks. amfetamin og stryknin, men også kokain eller cannabis. De anvendtes, fordi de $\emptyset$ gede præstationsberedskabet i forhold til umanipulerede sportsfolk. Da den bevidste kontrol over graden af udmattelse samtidig går tabt, er der ved siden af den forhøjede konkurrencepræstation en fare for kropsligt sammenbrud, der kan føre til døden. Grunden til denne potentielt dødelige »bivirkning « ligger i udnyttelsen af den »autonomt beskyttede reserve «, som man uden kemi (altså viljesmæssigt) overhovedet ikke ville kunne mobilisere. ${ }^{18}$ Denne udvikling er formodentlig forstærket gennem erfaringer fra 2. Verdenskrig og i tilslutning hertil blevet systematiseret, for f.eks. hørte en meget bittert smagende chokolade til de tyske soldaters nødration. Denne indeholdt store doser af opstramningsmiddel, der gjorde soldaterne i stand til at tage vagter af 48 timers varighed uden træthedsfølelse, hvorpå der imidlertid fulgte en fuldstændig udmattelse. Som det kunne vises, er disse midler i det mindste siden 1963 centralt projekteret og anvendt i DDR-sporten. ${ }^{19}$

Hvorfor blev anabolika først »anvendt« så sent? - diskussionen om en anvendelse begyndte sådan set tidligt? Ud af en spontan harme over funktionaliseringen af de unge elitesportsmænd og -kvinder, der tydeliggøres i Brigitte Berendonks bog, begyndte amerikaneren John M. Hoberman den historiske søgen efter spor, en analyse af den med hans ord »dehumanisering af sporten «, som fandt sted gennem dopingen. Bogen, i hvilken oprindelsen til sådanne skadelige overdrivelser eftersporedes, blev udgivet i 1992 hos MacMillan, et betydningsfuldt videnskabeligt forlag. Det er en udtalt fortjeneste for forfatteren, der drev en intensiv efterforskning af tiden fra midten af det 19. århundrede til NS-tiden, for første gang at have tematiseret sportsmedicinens og den tidlige sportsvidenskabs diskurser. Disse var på den ene side særdeles grundige og ikke tilgængelige for flertallet, på den anden side var de let funktionaliserbare, f.eks. i nazismen.

Hobermans anklage må derfor efterprøves nøjagtigt. Nærede dele af den sportsvidenskab, der konstituerede sig, fra 1930'erne sympatier for biologiske manipulationer med sportsudøverne? Viste der sig efter 1933 sågar kvalitetsændringer, da testosteron for første gang i 1935 kunne fremstilles? Fra 1920-1940 var der ifølge Hoberman en regelret debat i Tyskland, ved hvilken et flertal af præparater og medikamenters positive virkning blev diskuteret, men ikke altid med direkte relation til sporten. Professor Otto Riesser, direktør for Pharmazeutisches Institut der Universität Breslau, forholdt sig i en tale for svømmeforbundet i 1933 afvisende, hvorimod professor W. Poppelreuther fra Bonn og F. Hüppe skrev positivt. At de anabolika, der verden over fra 1930'erne principielt kunne tages i brug, forbløffende nok ikke blev anvendt i sporten, fører forfatteren tilbage til det medicinsk-psykologiske paradigme: Medicin og biologi havde kun udforsket og benyttet disse midler i deres seksuelle og reproduktive funktion, altså for seksualforskningen og til forsinkelsen af ældningsprocessen. »Kraft har ikke stået $i$ fokus og er quasi blevet overset « ${ }^{20}$

Indføringen af anabolika-doping har samtidig politiske grunde: De af Treutlein 
og Singler unders $\varnothing$ gte udviklingstendenser giver nemlig entydigt belæg for, at gennembruddet $i$ anabolika-doping tog sin begyndelse i tiden, hvor der var størst modsætning mellem øst og vest. I starten brugte begge antipoder i det bipolære verdensbillede anabolika: »US « og »SU « (USA og USSR), hvorved nye pharmakas optræden i elitesport i Vesten kan efterspores relativt nøjagtigt, da de efter at være blevet kendt udløste den kendte spiral blandt andre topatleter og i det omgivende milj $\varnothing .{ }^{21}$ For DDR kan det sågar bevises på det personlige plan, hvordan anabolika-dopingen blev integreret $i$ træningsmetodikken: Rektor for Leipziger Sporthochschule bragte i 1964 ideen med fra de olympiske sommerlege og forsøgte at begejstre sportsledelsen med dette »vidunder «. Interesse fandt han i første omgang kun hos ministeren for statssikkerhed (STASI), der åbenbart lovede fordele for den af ham foretrukne klub Dynamo, der som sportsorganisation for STASI samt for politiet og toldvæsenet havde et elitekrav. Netop i DDR blandedes, trods det officielt humanistisk-egalitære sportsideal, »afvigelse « og politiske motiver direkte paradigmatisk og (i bogstavelig betydning) »totalitært«. I løbet af godt et halvt år var det typiske $\varnothing$ sttyske tvangssystem opstået.

I 1960'erne kom det ikke kun i DDR til en vigtig forandring, da de farlige opstramningsmidlers betydning blev mindre (bl.a. fordi de ikke kunne bruges i træningsprocessen): Til gengæld var der så de allerede længe kendte anabolika: De fremmede muskelgennemsnittets vækst (»anabol virkning «), hvorfor de i sporten i hvert fald fra 1975 imod deres oprindelige medicinske indikation blev misbrugt til en generelt forbudt præstationsøgning. Der kan imidlertid også bevises en udpræget psykologisk virkning. Midlerne syntes harmløse i forhold til opstramningsmidlerne for de første »anvendere« (der var medicinske lægfolk, ikke stillede etiske spørgsmål og desuden endnu ikke besad kendskab til langtidsindtag). Et virkeligt gennembrud (i negativ forstand) skete med overgangen fra sprøjte til tabletter. Nu var medicinermonopolet i forbindelse med udleveringen brudt.

Ved siden af de anabolt virkende androgene stereoider henregnedes længe også de kemisk anderledes opbyggede, men svagt anabolt virkende $\beta$-2-agonister til denne gruppe. Problemet tog sin start med kalveopfedningsmidlet Clenbuterol@ , der nogle år tidligere blev misbrugt af nogle kvindelige sprintere og netop $i$ foråret 2000 igen blev fundet i en doping-prøve i Tyskland. ${ }^{22}$ Misbruget af meget farlige blodplasmaexpanders såsom HES, der stammer fra medicin til nødstilfælde, tydeligg ør, at en negativ-liste med forbudte substanser altid er bagefter doping-praktikken.

\section{Sundheden som begrundelse for doping-forbud og problemerne med de såkaldte bivirkninger}

Den medicinske diskurs - traditionelt orienterer man sig efter den »ikke-fysiologiske præstationsforøgelse«s tænkemodel skal ikke medtages, men den tematiseres i litteraturen. ${ }^{23}$ Via det tiltagende misbrug af opstrammende midler kom det til definition og forbud. Før eksakte undersøgelser afklarer, hvorfor dette afgørende indgreb i individets rettigheder indtrådte, kan truslen mod den sportslige chancelighed forstås som hovedgrund: Misbrugeren tilvejebringer pludselig præstationer, som han ikke havde kunnet yde uden »understøttelse $\ll$, og skader gennem dette bedrag den 
ærlige konkurrent. Dette kan overraske, for sundhedsbeskyttelsesmotivet var oprindeligt mindre vigtigt end dette. Åbenbart fulgte dette logikken i anti-doping-kampen i engelsk ridesport i det sidste århundrede. Der handlede det om resulteter, der blev ændret gennem doping og gjorde oddsene ukalkulerbare. Manipulerende jockeyer eller ledere måtte derfor frygte hårde straffe. Nogle organisationshistoriske rammedata beviser det endnu langsomme tempo, som sportsforbundene reagerede med: Først i 1968 blev doping-kontrol gennemført i forbindelse med konkurrencer, i $1970 \mathrm{kom}$ det til de første straffe efter positive undersøgelsesresultater (i vægtløftning). I 1972 blev anabolika forbudt i DSB (Deutscher Sportbund); i Den Internationale Olympiske Komite (IOC) og Det Internationale Atletikforbund (IAAF) blev de forbudt i 1974/75. Konkurrencekontrol til gennemførelse af forbuddet blev i første omgang kun gennemført i få sportsgrene.

Dette første skridt var efter mange kritikeres mening ikke nok. Det var åbenbart, at en rettidig »afbrydelse « af behandlingen førte til negative konkurrencekontroller. Samtaler med samtidsvidner om f.eks. svømning beviser, at tilhængere af anabolika sågar diskuterede ${ }^{24}$ hvornår de var nødt til at ende deres »kur «. Siden 1980/81 blev der derfor for første gang krævet trceningskontrol for at undgå, at den unfair bedrageriproces blev forskubbet til forberedelsestiden, men først fra 1989 blev disse forenklet og først fra 1991 praktiseret i betydelig grad. Denne »trussel « om afsløringen af misbruget i uanmeldte kontroller i træningsfasen har siden året for indførelsen, 1991, ført til en dramatisk tilbagegang i sportslige præstationer i næsten alle olympiske sportsgrene. At kvindesvømning udgjorde en undtagelse, ${ }^{25}$ hvor man i over et halvt årti undgik træningskontroller, be- grunder jo, hvorfor resultaterne ikke der gik tilbage. Dette skete først efter indførelsen af kontrollen.

Samtidig blev der med det Europæiske Fællesskabs (EF) anti-doping-konvention udviklet et regelværk på mellemstatsligt niveau i 1989, som også et utal af ikkeeuropæiske lande siden har tilsluttet sig. For nylig udviklede IOC Court of Arbitration, som skal dømme på højesteretsniveau. ${ }^{26}$ IOC's anti-doping-agentur konstituerer sig. Ud fra den forenings- og forbundsorganiserede sports synspunkt, fra eliteforbundene i Deutscher Sportbund (DSB) til verdensforbundene og IOC, har doping siden gennemførelsen af forbudene $i$ nasten et kvart århundrede været et tungtvejende regelbrud, der truer chanceligheden i den sportslige konkurrence. Aktørernes sundhed er et andet aspekt. ${ }^{27}$ For disse vidtrækkende aktiviteter lå følgende forståelse til grund, der i 1970'erne var den internationale og nationale doping-bekæmpelses reference: IOC's vurdering i dennes Medical Code tjener siden som grundlag i rets- og definitionsspørgsmål. Reglerne mellem forbudte virkningsstoffer (forbudte virkningsstofgrupper er: anabolika, opstramningsmidler, erythropoitin) og forbudte metoder (såsom blod-doping i betydningen egenblodtransfusion eller sløring af dopingtests).

Selvom anabolika sammenlignet med opstramningsmidler syntes harmløse for de første »anvendere « (som medicinske lægfolk), er tilførelsen af denne virkningsstofgruppe imidlertid ifølge faglitteraturen (også i DDR, der plæderede for doping) ikke uden biologiske følger: Det grundlæggende hormon testosteron styrer bl.a. udvikling af seksualorganerne, hvilket også gælder for de afledte anabolika. Tilførsel til doping-formål trækker derfor $» u \emptyset n-$ skede bivirkninger« med sig: skader på de 
indre organer, især leveren, men også på kønsorganerne og reproduktionsapparatet, på hjerte- og kredsløbssystemet og mange adfærdsforstyrrelser.

På området, der angår udviklingen fra barn til voksen, er det et hyppigt overbevisende argument, at den udbredte betegnelse »bivirkning « ikke er rammende pga. det falske perspektiv: Fra endokrinologiens synspunkt er den formentlige bivirkning det mandlige kønshormons egentlige »hovedvirkning «: Selvom også kvinden producerer testosteron (ifølge litteraturen ca. $10 \%$ af det, manden producerer), har »mandlige « koncentrationer netop også mandliggørende virkninger. De derved frembragte irritationer er - også dette overbeviser hyppigt - mest sammenligneligt med de humørsvingninger og pludselige forandringer, der næsten altid finder sted i puberteten.

Pga. den kønslige transformation påvirkes kvinder på særlig måde af anabolika. Kvinder - især piger - kan frygte en irreversibel »virilisering « (mandliggørelse) med mandlige kropsformer og behåring, acne samt dybere stemme. Brigitte Berendonk og Werner Franke har som betegnelse herfor anvendt »uomvendelig andronisering « af kvinden. »Risikoen for for tidligt afsluttet højdevækst« og »skadelig påvirkning af forplantningsevnen « kan desuden føjes til. Hos manden kan den i begyndelsen forstærkede kønsdrift føre til en »virkningsændring « med »feminisering « af udseendet, med dannelse af kvindelige bryster (!), hvilket fører til operation, i mindre grad af kosmetiske årsager end pga. risikoen for kræft. Artiklens forfatter kunne med udgangspunkt $\mathrm{i}$ originaldata fra den hemmelige DDR-sportsvidenskab nå frem til, at hver tredje kvinde gennem brug af doping-midler havde alvorlige bivirkninger på kønsorganerne. Yderligere kan en i 1998 gennem analyse og stikprøvefund op- stillet regel nævnes: Hvis en eller begge forældre var udsat for anabolika i elitesport, steg risikoen for fostermisdannelse og abort tydeligvis; ${ }^{28}$ samtidsvidner har bekræftet $\varnothing$ gningen af episoder blandt deres kvindelige kollegaer.

For historikeren er den ekstreme psykogene virkning (og dermed også narkomanipotentialet) ved f.eks. anabolika blevet tydeligt gennem skriftlige kilder og personlige samtaler. Ikke kun i den vesttyske litteratur er denne afhængighed ikke blevet diskuteret i et omfang, der kan sammenlignes med diskussionen af den fysiske afhængighed. ${ }^{29} \mathrm{I}$ det angelsaksiske område anses det betydningsfulde og negative $p s y$ kiske potentiale i mellemtiden for lige så vigtigt som det fysiske. ${ }^{30}$ Ligeledes er »moderne «, ja, »postmoderne « anvendelseskonceptioner såsom injektion af koldt opbevaret, syntetisk erythropoitin (EPO) eller kombinationen med midler til påvirkning af humøret endnu ikke blevet undersøgt tilbundsgående. Misbrugeren må derigennem - ligesom før 1970 - for første gang igen stå ansigt til ansigt med døden, nu ganske vist ikke gennem hjertestop pga. udmattelse, men som følge af emboli pga. blodfortykning i centrale kar. Dette fremprovokerer adfærdsstrategier, som (ved siden af trangen til at lyve om og dække over ting) på negativ vis måtte virke personlighedscendrende: elitecykelryttere må i forbindelse med indtagelse af EPO også regelmæssigt stå op under nattes $\varnothing v n e n ~ o g$ bedrive kredsløbsmobilisation for at forhindre blodprop.

Den nye doping-metode blev, om man vil, udviklet på »rekordtid«: i 1989, nøjagtig fem år efter den første syntese, blev EPO tilladt som medikament. Gennem sprøjter kunne man nu opnå effekterne af højdetræning, altså »forbedret udholdenhedsydelse«, ligesom gennem den ifølge 
de schweiziske forfattere Matthias Kamber, Primus Mullis og Martial Saugy fra 1950 praktiserede, højrisikofyldte egenblod-doping. Denne doping, der af IOC betegnes som »forbudt metode «, fungerede uden kemi, da eget blod blev konserveret og før konkurrencen igen bragt ind i kredsløbet. Som følge af det »overnaturlige antal af røde blodlegemer « skal der i laboratoriet have forekommet "præstationsforøgelser på næsten 10 procent «. Nogle amerikanske cykelryttere indrømmede at have brugt denne metode under OL i 1984. Bl.a. fordi 18 Benelux-cykelryttere og syv svenske orienteringsløbere døde af hjertesvigt i løbet af godt fem år, blev EPO-brug i 1990 forbudt af IOC, selvom det ikke hidtil er muligt at fastslå et misbrug. ${ }^{31}$ Ifølge samtidige vidners beretninger er denne praksis allerede tidligt meget udpræget i vinter- og sommersport i Skandinavien. ${ }^{32}$

\section{DDR-stats-doping - en analyse af et »afvigende system «}

»Doping i DDR « skal indlejres i en større kontekst, for stof- og medikamentmisbrug har ikke kun været et problem i DDR. Erkendelsesinteressen var i et kildeorienteret studie at finde ud af de påviselige saregenheder ved den i DDR statsligt organiserede tvangs-doping af de til enhver tid bedste 2.000 sportsmænd- og kvinder. Således kan de udarbejdede resultater quasi benyttes som undervisningsfelt, da sikre undersøgelsesresultater om misbrug i DDR støtter kendte argumenter og for første gang empirisk beviser hidtil kun postulerede argumenter (såsom bivirkningerne). Ved det statsligt organiserede misbrug handlede det om et »lukket system «. ${ }^{33}$ Årligt har ca. $10 \mathrm{~kg}$ Oralturinabol ${ }^{\circledR}$ fra Jena sørget for, at de olympiske medaljer kunne vindes af borgere fra DDR. Vundet efter ordre fra Det Socialistiske Enhedsparti, med udenrigsrepræsentation og magtsikring som formål. Dette hændte i en stat, der siden 1961 blev holdt sammen af et grusomt grænseanlæg og kun få integrationsfaktorer, til hvilke udlandets anerkendelse som følge af elitesport hørte? Hormoner og stoffer som ordre fra partiet?

Som på næppe noget andet område i DDR-samfundet er »devianz«, fagtermen for social afvigelse, for uønsket opførsel, en hæmsko ved undersøgelsen. Vurderingen af doping-komplekset kan ud fra et mentalitetshistorisk aspekt sammenlignes med socialt foragtede handlinger, som f.eks. illegal abort eller i den videnskabelige sektor en succesrig konkurrencekamp, som ikke bliver opbygget på dygtig ledelse, men kun på aktiv eller passiv bestikkelse. Netop herom handler det i øvrigt også her. Ja, selv mangt et offer kommer af sporet pga. fortrængning eller svigtende erindring, så at de i den historiske proces opståede originalkilder igen og igen må inddrages.

$» H v e m$ retfardigg $\phi r$ moralsk og sundhedsmassigt anvendelsen af anabole stereoider? « Dette spurgte man for efterhånden lang tid siden om ved en tysk kriminalret: Det skete i 1970 'erne i DDR og vidner om gerningsmændenes »uretsbevidsthed «, som pars pro toto - samtidig spurgte de bekymret: »Hvem skal egentlig vare ansvarlig for det? « Den, der stillede spørgsmålet, var »opfinderen « af statsdoping: professor, dr. Hans Schuster. Han stillede begge disse spørgsmål, der var så vigtige i både det centralforvaltede og pluralistiske samfund. Det handlede i temaområdet doping - dette kan ikke betones tit nok - om afvigende adford. Den, der var bundet i det konspirative og DDR-lovovertrædende tvangs-dopings-system (trænere, læger, videnskabs- 
mænd og funktionærer), er derfor i reglen uegnet som kilde til historisk rekonstruktion. Ud fra et juridisk synspunkt blev der fastlagt en principiel dom i en proces, som en doping-involveret (kvindelig) læge førte mod artiklens forfatter: Konklusioner, der er kommet i stand i overensstemmelse med reglerne for (historie)videnskaben, kan ytres, selv hvis den, disse vedrører, dementerer sandhedsindholdet. Det er ikke at forvente, at samtidsvidner svarer objektivt i dette temafelt, hvorfor de ikke skal høres. Den klagende læge, der stadig er ansat ved IAT Leipzig, måtte endda tage imod den formulering, at hun ifølge retten $» \ldots d e l$ vist - om end det ifølge hende skyldtes medicinske åsager - har udleveret midler, der er opført på dopinglisten «. Ligeledes har hendes procesbefuldmægtigede $»$ indrømmet «, at der derved »kunne vare tale om det i DDR ikke tilladte middel STS646«. ${ }^{34}$ Ifølge forfatterens erfaring har højt placerede embedsmænd afgivet urigtige interviewudtalelser. ${ }^{35}$ De skriftlige kilder, der er opstået i den aktuelle, samtidige sammenhæng, har derfor i regelen forrang. Ministeriet for Statssikkerheds (STASI) omgang med sagsakter, sagsdokumenter vedr. gerningsmænd og ofre i DDR's ministerråd fordrede særlig omhu. ${ }^{36}$ Uden nogen som helst undertone må det fastslås: Heller ikke ofrenes ytringer kan bruges uden kildekritik, fordi der fandtes forvrængninger af erindringen gennem indre »kvæstelser « i herskabssystemet DDR-»præstationssport $\ll$.

\section{Historiske faser $i$ anvendelsen af »underst $\phi$ ttende midler $i$ DDR}

»Underst $\varnothing t t e n d e$ midler « var i DDR-præstationssport farmaka og metoder, der på anabolika-basis tjente den kunstige præstationsstyring. Også stoffer, der på anvendelsestidspunktet endnu overhovedet ikke var blevet sportsretsligt forbudte, blev hemmeligt anvendt til præstationsøgning. ${ }^{37} \mathrm{Her}$ tog i øvrigt et spørgsmål fra Arnd Krügers sit afsæt efter et foredrag af undertegnede, afholdt ved Hochschultag i Bayreuth: Han ville vide, om der efter min overbevisning var tale om en doping-forbrydelse fra DDR-sportens side, når et middel endnu ikke var at finde på forbudslisten. Ved svaret må man efter min overbevisning skelne mellem på den ene side formaljuridiske positioner og på den anden en dopingmentalitet, der bedriver misbrug af et præparat, der - af den ene eller anden årsag - (endnu) ikke er forbudt, eller som der allerede er anticiperet et forbud imod - som det var tilfældet med testosteron.

En pracanabol fase begyndte i 1964 med grundlæggelsen af DDR's sportsmedicinske Tjeneste (SMD): Her blev »klassiske« opstramningmidler »indsat «. Efter forslag fra rektor for Deutsche Hochschule für Körperkultur, professor Schuster (der samtidig var »Inoffizieller Mitarbeiter «) gav ministeren for statssikkerhed, Erich Miel$\mathrm{ke}$, ordre til at udvikle anabolika-metodikken i sportsklubben Dynamo (SVD) (Dynamo hørte via Ministeriet for Statssikkerhed og Indenrigsministeriet til i den statslige sektor). I 1968 kom det her til en anvendelse af anabolika, og eftersom dette blev en succes, bredte anvendelsen sig fra 1972 til hele den $\varnothing$ sttyske elitesport. Den utøjlede brug af anabolika antog snart et kritisk omfang, hvilket her skal betegnes som den decentrale anabole fase. Den $\emptyset$ nskede centrale regulering gennem DDR's sportsmedicinske tjeneste samt forordningen af centrale »anvendelseskonceptioner « for dosering og periodisering af de mange dopingsubstanser via den (øst)berlinske sportsle- 
delse fungerede ikke. Interne forbud var virkningsløse; først indførelsen af kontrol ved konkurrencer fremtvang en samlet »afbrydelse« af anabolika før afrejsen til konkurrencer.

I denne situation, der pga. faren for afsløring af det ekstreme misbrug var særdeles eksplosiv, prægede en intern styring $\mathrm{i}$ 1974 strukturerne i medikamentmisbruget. Indtil 1990 kan man tale om en central anabol fase - seksualhormoner udgjorde fundamentet i træningsmetodikken for den nationale elite af juniorer og seniorer. Forvandlingen indtrådte via Die Leistungssportkommission der DDR (DDR's elitesportskomission), en vedtægtsløs kommission under SED-centralkomiteen. Denne »SK « blev enig om en omfattende anlagt »masterplan «. Denne forpligtede alle deltagende til årligt i samarbejde med trænere og videnskabsmænd uforandret at anvende udarbejdede centrale retningslinjer for doping-praktik udarbejdet af læger. Yderligere skulle deres pro-doping-forskning nu integreres $\mathrm{i}$ en samlet planlægning, og de skulle minimere de »uønskede « bivirkninger, som uden tvivl fulgte med de »understøttende midler «. Samtidig gav man afkald på grundlæggende forskning i virkningsmåden - i stedet satsede man på anvendelsen og søgning efter nye midler. Til denne anvendelsesforskning blev der ansøgt om såkaldte Staatsplanthemen. Nu var den statsligt kontrollerede og finansierede konspirative tvangs-doping opstået: Doping uden sportsfolkenes vidende og uden forældrenes samtykke, når der var tale om mindreårige doping-ofre. Med den truende indføring af træningskontrol for øje planlagde man fra 1987/88 overgangen til en postanabol fase, der på trods af mange eksperimenter imidlertid ikke lykkedes.

\section{Hvorfor doping-midler blev »sikret« af SED-politbureauet}

DDR's gennembrud i verdenssporten mellem 1968 og 1972 beroede i afgørende grad på integrationen af anabolika i træningsmetodikken for begge køn: Efter de fremragende resultater i 1968 og 1972 måtte et fald i præstationerne (der i $\emptyset$ vrigt ville have virket afslørende) forhindres. Ved OL i 1976 skulle radikal doping-anvendelse sikre den opnåede position. Fra da af blev doping også anvendt på talenterne $\mathrm{i}$ »udvælgelsestræningen « (altså den sene junioralder). Disse praktikker var i DDR juridisk set ulovlige, hvorfor man indførte camouflagebetegnelser. Formodentlig for at gardere sig ved dødsfald nævnte man »underst $\varnothing t t e n d e$ midler « og »Staatsplanthema 14.25 « i tre grundlæggende, naturligvis hemmelige politbureaubeslutninger - i hele 12 år! Først i september 1989 førte udenrigspolitiske hensyn til ændringer: Den kompromisløse Manfred Ewalds efterfølger som DTSB-præsident og formand for den (hemmelige) præstationssportskommission, Klaus Eichler, anmodede for første gang siden indføringen et kvart århundrede tidligere om, at man afskaffede den centrale doping.

Hans $\varnothing$ nske blev imidlertid ikke opfyldt, for sportsminister, professor, dr. Günter Erbach samt andre doping-fagfolk overbeviste ham om, at præstationsniveauet ikke kunne opretholdes uden doping-midler. (Eichler kan muligvis takke forfatterens fortolkning på dette sted for indstillingen af retssagen pga. delagtighed ved kropsbeskadigelse gennem doping-midler.) For os er dette forløb desuden et enestående bevis på DDR-træningsmetodikkens videnskabeligt beviste afhængighed af doping-midler. 


\section{Ansvarsområder og antallet af distributфrer}

Præsidenten for DTSB bar det samlede ansvar og havde afgørelsesbeføjelse i alle doping-spørgsmål inklusive dispensation i hemmeligtstemplede sager. Præsidenten kunne give ordrer til den fuldtidsbeskæftigede vicepræsident og var i sportsspørgsmål faktisk ligestillet med den statslige ledelse. Ewald var som valgt medlem i SEDcentralkomiteen forpligtet til i dopingspørgsmål at aflægge regnskab over for den sportsansvarlige sekretær. Dette var Paul Verner, derefter Erich Honecker og slutteligt Egon Krenz. SED's interesser havde altid forrang. Dr. med. Manfred Höppner var leder for »Leistungssport II « $\mathrm{i}$ SMD-ledelsen og den »centrale arbejdsgruppe for underst $\varnothing t$ ttende midler «, der var underordnet LSK. Præsidenten for DTSB blev regelmæssigt informeret af Höppner omkring udlevering, indsats og anvendelse. Således fik SMD informationer, selvom dette var tjenestemæssigt problematisk. Höppner, som Ewald også var patient hos, måtte i alle vigtige spørgsmål konferere med Ministeriet for Statssikkerhed: Sådan kunne ministeriet varetage dets egne interesser, da Dynamo grundlæggende lod hånt om UM-retningslinjernes grænseværdier.

Staten finansierede forskningen i og anvendelsen af doping, selvom den var underlagt sundhedslovgivningens og den lægelige standrets normer. Statssekretæren for sport var pennefører, hans stedfortræder, professor, dr. Edelfrid Buggel, var som leder af »Arbeitsgruppe Wissenschaft« (AGW) under LSK statslig ansvarlig for »forskning og udvikling « (F/E) på dopingområdet. De statslige opgaver inden for forskning var fastlagt $\mathrm{i} \gg$ Komplex 08-Plan Nr. Zf. 14.25 i i statsplanen over videnskab og teknik og bandt den medvirkende stor- industri, som også fremstillede dopingmidler til eksperimentelt brug. »Statsplantema 14.25 « relaterede sig følgelig derfor ikke til doping-anvendelsen i DDR, men til forskningen.

Forskningsgruppen »Zusätzliche Leistung « ved Forschungsinstitut für Körperkultur und Sport (FKS) i Leipzig med professor Alfons Lehnert som »temaleder « tog sig af forskningen. »Kooperationspartnere« blev inddraget i sportsministerens ansvarsområde i koordinering med LSK, der bl.a. talte Zentralinstitut für Mikrobiologie und experimentelle Therapie (ZIMET) i Jena med dets leder (der samtidig var registreret som uofficiel medarbejder) og Institut für Klinische Pharmakologie der Charité. Det farmaceutiske Kombinat GERMED i Dresden og VEB Jenapharm fremstillede som $\varnothing$ konomiske instanser præparaterne, for så vidt disse ikke vha. valutainvestering konspirativt skaffedes direkte i udlandet via den kommercielle koordinering (under Alexander Schalk-G.) eller STASI ${ }^{38}$ I det centrale forskningsinstitut SMD i Kreischa lå det IOC-akkrediterede doping-kontrollaboratorium. Begge statslige institutioner blev misbrugt til dopingformål, hvad det imidlertid ikke var alle medarbejdere, der var klar over.

Uden for sportssektoren havde f.eks. fagministeren for kemiindustri og præsidenten for Akademie der Wissenschaften kendskab til doping-praktikken. ${ }^{39}$

Antallet af delagtige synes at være betydeligt højere, end hidtil antaget: Som minimum kan man antage 1.500-2.000 personer, som var beskæftiget med videregivelse eller anvendelse af doping-midler. I sportsklubberne har formentlig mellem 700 og 1.000 trænere, funktionærer og sekretærer indtaget en aktiv rolle. I sportsmedicinsk tjeneste er det formodentlig en tredjedel af personalet, altså 700 læger 
samt sygeplejersker o.lign. og funktionærpersonale, der har medvirket.

\section{Flere fordelingsveje end der svarede til den centrale planlagning}

Det kunne bevises, at hæren og Dynamo via deres egne apoteker skaffede og anvendte yderligere doping-midler - altså uden centralt kendskab eller tilladelse. Desuden blev der gennem SMD-ledelsen i Berlin skaffet præparater, som blev opbevaret og mod kvittering udleveret til forbundslæger og repræsentanter for de »sportslige hovedrådgivningssteder « (SHB) under SMD. Disse rådgivningssteder i de 15 amter var beskæftiget med fordelingen af alle »u.M $\mathrm{M}$ (understøttende midler). I reglen overgav stedfortræderen for områdets sportslæge, næsten altid »Abteilungsleiter Leistungssport « (i et enkelt tilfælde sågar en forvaltningsansat, helt præcist en chefsekretær), præparaterne til sektionslægerne. Disse havde i overensstemmelse med skriftlige planer talt præparaterne op og pakket dem neutralt (i små glasrør) for at videregive dem til trænerne. De tomme originalindpakninger skulle destrueres af lægen (ved gennemsnitligt 140 anabolikasportsudøvere pr. klub drejede det sig om cirka 40 æsker Oralturinabol® om dagen pr. sted). Træneren traf beslutning om den konkrete dosering, men ikke om hvorvidt en sportudøver skulle inddrages i eller udelukkes fra misbruget. De aktive kunne indtage midlerne i trænerens nærvær, eller de fik udleveret tilstrækkelige mængder til et par dage (vægtløftere). Sprøjter med anabole substanser (kropsbeskadigelse) blev givet af læger. Ordinering og indtagelse af hormonelle antikonceptiver (»pillen«) var pligt allerede i pigealderen, fordi anabolt virkende midler blev udvalgt til dopingformål.

Mindst tre fordelingsveje forstærkede misbruget. Den første vej gik efter reglerne ud fra, at såvel arten af doping-midler som anvendelseskonceptionerne blev fastlagt fornuftigt og i centrale retningslinjer. Dette var imidlertid ønsketænkning, fordi den nationale konkurrence mellem civile DTSB-klubber og militærsport og Dynamo i praksis trak alle tænkelige udvækster med sig. Der herskede på intet tidspunkt overskuelige forhold. Den anden vej var anskaffelse, forskning og anvendelse efter ordre fra den lokale SED-distriktsledelse. Som tredje vej kan man se den individuelt foretagede selvmedikation i alle varianter. Denne skete på eget ansvar og var et bevidst brud på doping-reglerne: Der var tale om lovbrud i forbindelse med anskaffelse (det sorte marked, import) for at opfylde normerne eller blive i stand til at vinde $\mathrm{i}$ træningsgruppens eller klubbens konkurrencer. Som fjerde vej kan man se dopingeksperimenterne hos kader-atleterne og normale sportsinteresserede samt eksperimenterne med psykofarmaka i NVA-forsøgsanstalten i Königsberg og i undertrykskammeret i Kienbaum med militærpersoner fra alle præstationsniveauer med anabolika og farmaka. Den ulovlige anvendelse i rekrutterings- og amatørsporten lader sig ikke klart fastlægge. Det første anmeldte doping-tilfælde, der vedrørte en DDR-sportsudøver, angik en kvinde, der som bodybuilder var blevet testet positiv. Alene den tredje vej ligner det, der var muligt i det frie samfund før indførelsen af træningskontroller. Derfor var brugen af doping-midler i DDR formodentlig altid højere end i stater uden central distribution. Motiver for uautoriserede praktikere var i denne retning af materiel natur, ikke, som man kunne tro, læger og træneres ven- 
lighed over for enkelte sportsudøvere, og skal derfor i særlig grad bedømmes etiskmoralsk.

Væsentligt større andele end i den $\varnothing v r i-$ ge elitesport var aktive som »uofficielle medarbejdere « på doping-området. Hemmelige manipulationer førte til uddelegering med falske angivelser, videregivelse af patientdata hos psykologer, eller lægeIM skadede patienterne.

\section{Frafaldsfanomenet og de aktives medviden}

Akter og interview henviser til »afbrydere«, der efter konfrontationer med dopingmidler eller bivirkninger har besluttet sig til at redefinere deres professionelle mål. Dette gør sig gældende på alle felter: For aktive, læger, videnskabsmænd, men imidlertid især for trænere. Yderligere er der ingen henvisninger til, at nogen er blevet tvunget til mod deres vilje at arbejde i doping-sektoren. Ganske vist måtte man ved tilbagetrædelse underskrive en $\gg$ tavshedserklæring under strafansvar « til beskyttelse af »statshemmeligheder «.

Sportsudøvere fik faktisk tilladte og ulovlige præparater fra trænerens eller sektionslægens »hånd « (sprøjter) uden oplysning om disses virkningsmåde, risici og bivirkninger. Spørgsmål var uønskede og førte til udelukkelse. Ved eksperimenter med mennesker blev forskrifterne ikke overholdt: eksakt oplysning, skriftligt samtykke, overholdelse af minimumsalderen. Kun når medvirken var sagligt nødvendigt, blev ofrene helt eller delvist informeret. Dette var forbundet med skriftlige $\gg$ tavshedserklæringer «. Ofte blev tabletter opløst i drikkeflasker, så f.eks. unge kvindelige svømmere eller deres familie ikke kunne danne sig mistanke, eller en præsta- tionsfor $\varnothing$ gelse ikke kunne bringes i forbindelse med medikamenter. Det hemmelige indlæringsmål kan beskrives som følger: De aktive lærte ikke at spørge om virkning og følger samt formodede doping-foranstaltningers lovlighed, men derimod at fortrænge eller acceptere bedragets mulighed. ${ }^{40}$ Forfatterens research i Leipzig viste, at doping-midler blev inddraget uden for sporten, i ballettræningen, men at der her fulgte en oplysning om risici, og at en underskrift blev indhentet fra danseren eller dennes værge.

\section{Antallet af ofre for den konspirative tvangs-doping og formodede bivirkninger}

Siden 1972 blev mindst 2.000 personer om året ofre for den sportsretsligt ulovlige doping-anvendelse. På grund af distributørernes etisk lige så forkastelige destruktion af de skriftlige materialer kan vi i dag kun fremsætte skøn. DTSB gik ved inkorporeringen af nye »topydere « i nationalmandskaberne ud fra en karrierelængde på to Olympiade-cykler (otte år). Alt efter definitionen af de pågældende spotsudøvergenerationer kan skønnet starte med 6.000 DDR-borgere, men tenderer nok 10.000 aktive, som var udsat for tvungne »anvendelseskonceptioner med understøttende midler «.

Differentieret viden om bivirkninger fandtes pga. det centrale informationsvæsen hos de personer, der deltog i tildelingen: I de centrale »retningslinjer « var der fastlagt grænseværdier, som var begrundet sundhedsmæssigt. På årlige kurser i »trænerrådet « eller på efteruddannelsen (!) henviste man i detaljer dertil. Seneste aktfund viste, at der trods anabolika-fremkaldte leversygdomme stadig fandt udde- 
ling sted, og at trænere for udlandsindsatsen noterede sig deres atleters sundhedstilstand i kodet form - sundhedstilstanden i relation til doping-midlerne. Undgåelse af bivirkningerne spillede ganske vist en teoretisk rolle, men trods den strafretslige problematik blev det medicinsk indikationsløse misbrug ikke afsluttet før 1990.

For at få overblik over tabene, kan man unders $\emptyset$ ge DDR-papirer, der tillader mere nøjagtige skøn: 10-15\% af sportsudøverne havde lidt af lette forstyrrelser, der forsvandt efter afslutningen af misbruget. Yderligere 5\% kunne forvente varige forstyrrelser (stemme- og hudændringer blev ligesom mandlig behåring ikke talt med som svære forstyrrelser). Kun 80-85\% af de dopede blev ifølge officielle angivelser forskånet for bivirkninger. Ud fra et historisk synspunkt må alle data imidlertid til enhver tid anses som minimumsangivelser. Hos 500 af de omkring 10.000 dopede DDR-aktive kan man derfor forvente følger som hjertemuskel- og leverskader, kræftsygdomme og høj tidlig dødelighed, samt gynækologiske skader. (Dette vil jeg betegne som andringer affanotypen).

Som eksempel på et eksakt (naturligvis internt) følgeskøn skal et internt arbejde inddrages: Her berettes på basis af 85 mænd og 60 kvinder om følgerne af den (tvungne) indtagelse af Oralturinabol ${ }^{\circledR}$ samt om et klinisk-epidemologisk studie over syv år af anabolika bl.a. blandt 174 sportsudøvere inden for springdisciplinerne. ${ }^{41}$ Empirisk faktum er: $10 \%$ af de kvindelige sportsudøvere led af akne og hirsutisme, ligesom $8 \%$ led af ændringer på det libidinøse område samt af potens- og fertilitetsproblemer. ${ }^{42}$ Mere end en tredjedel af disse kvindelige sportsudøvere havde lidt under alvorlige gynækologiske forstyrrelser. Andre bivirkninger på forplantningen er endnu ikke blevet undersøgt; samtaler med samtidsvidner og STASI-akter lader formode, at dødsfødsler og misdannelser på børn har ligget tydeligt over befolkningens gennemsnit, selv ved beskedne anabolika-misbrug (her foreligger ifølge min overbevisning en principiel andring af genotypen). Et forskningsprojekt er her $\varnothing n-$ skeligt. Samtidige vidner forklarede eksempelvis forfatteren, at det tidligst var tilladt (!) at avle børn seks måneder efter en konkurrence, og at man for at undgå aborter måtte ansøge herom hos sportsklubben.

\section{Nagtelse af politisk og retslig vurdering før 1990: Fri doping}

Ingen havde indtil 1989 som SED-medlem anmeldt de ulovlige tilstande ved indberetning på statslige kontorer eller hos domsmyndigheden. Domsmyndigheden har i et procedenstilfaclde i 1975 (i Leipzig) efter forhandlinger med elitesport og Ministeriet for Statssikkerhed udtrykkeligt givet afkald på en retslig vurdering - indtil DDR's endeligt. Berørt var f.eks. kropsbeskadigelse, lægemiddellov, bevilling, økonomisk anvendelse af folkets ejendom; overtrædelse af forordninger i DTSB; ulovlig praktik i statssekretariatet og Sportsmedicinsk Tjeneste. Under foragt for menneskerettighederne har mange bivirkningstilfælde gennem indgreb fra Ministeriet for Statssikkerhed officielt ikke eksisteret eller er blevet skjult. Doping var faktisk frigivet. Betegnende nok, efter »die Wende «, den 29. januar 1990, anmeldtes så for første gang de centrale doping-praktikker ved en sportslæges indberetning hos ministerpræsident Modrow. Indberetningen fik dog ingen følger for gerningsmændene, fordi de blev sendt til behandling hos den dopingansvarlige i statssekretariatet, professor 
Buggel. Derimod fik den følger for den indberettende sportslæges karriere.

\section{Teser til historiske \\ saregenheder ved DDR- dopingen}

Selvom den systematiske og tvungne doping som vist var en afgørende faktor for DDR-sportens succes, så førte stofintegrationen ikke til et »sportsvidunder «, men til en »indbildt blomstring «. Denne kunne ikke have været styret uden en indsats med »underst $\varnothing t t e n d e$ midler«. Denne praksis er imidlertid i modstrid med det egentlige $\mathrm{i}$ sporten. Af denne grund bliver aktørernes adfærd i DDR ikke blot beskrevet, men også bedømt under et aspekt af politisk og især etisk ansvarlighed. Referencepunkter er for det første den doping-frie sport som idealtypisk konstruktion, for det andet doping-praktik i andre lande, der var sammenligneligt uudviklede. Ofte spørges der til DDR-dopingens sammenlignelighed med andre af dopingens fremtrædelsesformer. Derfor skal det afsluttende i teseform fremhæves, hvad der udgør det særlige ved DDR-doping i forhold til andre former og samfund.

1. Som regel kom det pga. kadertilhørsforholdet og uden atleternes medvirken til tvangs-doping.

2. Tvangs-dopingen var under statslig opsyn og blev gennemført med statslig finansiering.

3. De aktives medviden og medvirken var undtagelsen.

4. Doping-praktikker var faktisk juridisk frigivet, ved siden af sportens selvstyring stod den hemmelige tjenestes overvågning.

5. Sportsforbundenes centrale doping- retningslinjer og -planer regulerede sågar doseringen for den enkelte atlet.

6. Den hemmelige tjeneste og stridskræfter samt et politisk parti (SED) muliggjorde hinsides centrale normer den yderligere forsyning af doping-midler; de udviklede og finansierede egne praktikker.

7. En betydelig andel af doping-midlerne bestod af illegale eksperimentsubstanser med ikke-klarlagte bivirkninger og følgevirkninger.

8. Alle udvalgte aktive i en doping-sportsgren blev dopet; afslag var ikke muligt.

9. Atleter havde en lang doping-karriere, fordi man begyndte opnåelse af tærskelværdien allerede i junioralderen (i teknisk-kompositoriske sportsgrene og svømning i barnealderen).

10. Ved statslig hemmelig forskning søgtes metoder til sløring af dopingpraktikker (hemmelige »udrejsekontroller« m.h.p. overholdelse af de foreskrevne doseringer og »overgangs-doping « i konkurrencefaserne).

11. Statslig hemmelig forskning var hovedsageligt anvendelsesorienteret uden forinden at udforske virkninger.

12. Differentieret kendskab til negative sundhedsmæssige bivirkninger var ikke blot til stede i systemet, men pga. den retslige undtagelsesstilling grundlag for den lægelige aktivitet og træningsmetodikken.

13. Grundlag var permanent lægelig kontrol af doping-specialister uden frit lægevalg og uden ærlig infomation om den sande sundhedstilstand.

14. Det sportslige resultat blev betragtet som vigtigere end den aktuelle eller fremtidige sundhedstilstand.

15. Sundhedsdata efter karrierens afslutning blev forfalsket, uden ofrenes vidende. 
16. For at hemmeligholde følgerne af doping var der tale om tvangsindsættelse af skadelidte i egnede jobs. ${ }^{43}$

\section{Konklusioner og desiderater}

Historikeren kan ikke undlade at tænke sine resultater til ende, hvorved der kunne fremkomme henvisninger til bekæmpelse af doping. Siden åbningen af DDR's grænser er den intensive samtidshistoriske gennemarbejdning begyndt på alle områder. Men også $\mathrm{i}$ retten er mange tilfælde af kropsbeskadigelse gennem doping-praktikken i DDR-sporten i mellemtiden blevet vurderet juridisk. Senest måtte den mangeårige direktør for den sportsmedicinske tjeneste i DDR tage imod en bødevedtagelse fra amtsretten Berlin-Tiergarten. If $\varnothing$ lge denne havde han ydet hjælp til 109 tilfælde af kropsbeskadigelse gennem doping-praktik. En stedfortræder blev i første instans dømt til et halvt års betinget fængsel pga. delagtighed i kropsbeskadigelse på kvindelige svømmere og atletikudøvere i 72 tilfælde. ${ }^{44}$

Dette juridiske arbejde bestyrker sportshistoriens kildeunderbyggede resultater $\mathrm{i}$ kvaliteten, men også i kvantiteten, for - på basis af den ovenfor skildrede antagelse om $10 \%$ alvorlige skader hos dopingofre resulterer de 109 tilfælde, der blev påvist ved retten, i 1.090 »dopede« sportsfolk. Da det hidtil kun er processen i Berlin, der er afsluttet, bliver dette tal med sikkerhed højere og vil principielt bekræfte de i monografien forelagte vurderinger. Yderligere skal man tænke på, at det ved retten handler om nøjagtigt beviste enkelttilfælde, således at tilfælde, der er sværere at bevise, ikke bliver forhandlet i denne retning.

Hvordan klimaet har ændret sig via pressen og sportsvidenskaben, viste eksemplet med Frankrig, der nævntes i ind- ledningen. Endnu i 1995 endte et tilfælde med hormoninduceret kræft hos en mindreårig kvindelig eliteroer, der blev trænet af en tidligere DDR-forbundstræner, der var involveret i doping, med i retten at blive afsluttet uden afklaring (i øvrigt handlede det om det aktuelle Nandrolon). Denne artikels forfatter fungerede som vidne $\mathrm{i}$ forbindelse med muligvis benyttede DDRdoping-praktikker. Kun tre år senere fandt undersøgelserne af cykelsporten sted $i$ en ucendret lovsituation, hvilket henviser til følgerne af et doping-fjendtligt klima i den statslige omgang med problemet.

Hvis man kan lære noget af historien, så viser analysen, at inden for DDR-sporten, et professionsportsligt system med egentlig doping-frigivelse, er alle internationale konkurrencekontroller med én undtagelse succesfuldt blevet snigløbet. Først indførelsen af træningskontroller (random control in the process of training) og kontroller efter konkurrencerne bevirkede en ændring. DDR havde som følge heraf beviseligt allerede i 1989 måttet begrænse deltagerantallet til mindre end 70\%. DDRsporten ville ikke efter integration i et effektivt doping-kontrol-system have kunnet fortsætte den $\mathrm{i}$ cirka 20 år praktiserede adfærd: Denne beroede nemlig på, at der pga. de lukkede grænser eksisterede en fuldkommen rådighed over alle sportsfolks biologiske funktion. Nu skulle man pludselig åbne landet for stikprøvekontroller og kontroller efter konkurrencerne. Overført på nutiden ville et effektivt system med kort varselssystem følgelig være et sikkert middel til at opdage og afskrække i det mindste misbrugere af de stærkest virkende doping-midler (opstrammende stoffer og hormoner) uafhængigt af, om doping-programmer blev gennemført ud fra individuelle, økonomiske eller statslige motiver. 
DDR's forskning i doping-midler, der formodentlig er enestående i verden, har vist, at nye midler, der ikke findes på forbudslister, løbende kan misbruges til doping-formål. Derfor kom det til et væddeløb mellem misbruget af og forbudet mod nye midler, hvor forbudene afgjort kunne blive forhalet af DDR-repræsentanter i internationale forsamlinger (eksempel: neurohormoner eller epitestosteron-test). I en diskussion med Krügers legalitetsindsigelse fra 1997 kunne følgende alternativ udvikles: For at undgå at vare retsligt tvunget til at tolerere et misbrug, indtil et formelt forbud blev vedtaget, kunne listen vendes om. På listen skulle kun nævnes præparater, hvis anvendelse var tilladt for deltagere ved internationale sportsbegivenheder. Anvendelse af ethvert andet end de på listen tilladte substanser betød dermed automatisk et positivt doping-tilfælde. Således ville man kunne forhindre f.eks. indtagelsen af nye maskeringsmidler eller hidtil uanvendte præparater som i tilfældet med HES. Indtil enhver ændring af den nye regelsæt ville der vare retssikkerhed for doping-kontroller og for alle anvendere af præparater og substanser.

Studierne kunne vise, at den konspirative tvangs-doping i DDR svarer til de af Bette og Schimank udarbejdede teoretiske indledninger, selvom Vestens individualiserede mønstre her skal overføres på det centralt organiserede misbrugs kollektive aktører. At de biografiske og strukturelle sammenhænge ligefrem kunne forekomme som uundgåelig tvang til doping, fremstår dog ikke entydigt: Den nyere dopingforskning fastlægger nemlig, at der trods disse lovmæssigheder regelmæssigt eksisterer »afbrydere« eller endog total-nægtere, som åbenbart stiller etiske eller andre motiver før de materielle eller biografiske. Dette gælder sågar i tilfældet DDR lige- som i Vesttyskland (som analyser af den pædagogiske indvirkning på atleter har vist) ${ }^{45}$

De indblik, der er opnået igennem sportsvidenskabelig analyse, orienterer ikke kun om det problematiske område tvangs-doping i DDR, men tilbyder også læremuligheder i forebyggelsen mod stoffer, der kan forstås som en opgave for interdisciplinær forskning. En begyndelse er allerede gjort med to arbejdskredse på den sportsvidenskabelige Hochschultag i 1999. ${ }^{46}$

Det er sikkert for tidligt at ville skrive doping-historien. Før længdesnittet og sammenligningen har guderne, når alt kommer til alt, sat det eksakte studie af enkelttilfældet. De Mondenard har f.eks. fors $\emptyset \mathrm{gt}$ at analysere alle tilgængelige tilfælde fra alle tider. Han og Allessandro Donati har detaljeret beskrevet forløb i deres stater - såvel misbrug som funktionærers tildækningsfors $\emptyset \mathrm{g}$. For DDR har et stort antal journalister og sågar for første gang tyske civil- og strafferetter for nyligt fors $\varnothing \mathrm{gt}$ at udforske systemet og forfatningsretten. På denne basis bliver netop anabolika-doping i Vesttyskland og sportsvidenskabens og -forbundenes adfærd behandlet. Også undersøgelserne på baggrund af en EPO-manipulation, der er udgået fra et norditaliensk centrum og åbenbart har omfattet hele Europa, vil sikkert snart tillade sikre udsagn om, hvorvidt der måske findes et Vesteuropæisk doping-kartel. Efter at det står fast for Italien, at den yderst lukrative handel med sportsstoffer er i mafiaens hænder, venter en selvforvisning $i$ forvejen på svar: Er der også nord for Alperne tale om, at et finansstærkt stofkartel regulerer distributionen? Hvem ville det undre, hvis indenrigsministeren også her støder på organiseret kriminalitet?

Hvis man indlader sig på at efterprøve 
genstandens historicitet, fastlægger man, at det desværre handler om et genuint område inden for elitesporten. Området har fået sin for misbrugere åbenbare værdi i det øjeblik, da den målbare sejr samfundsmæssigt fik højere værdi: I et kvantespring får denne bedragsvariant pludselig ny betydning, da »sejren « bliver materielt belønnet: Fortrinsvis kunne man opnå tings- og pengepræmier eller - i plan økonomiske-egalitære samfund - privilegier, der var penge værd. For disse gratifikationer stod tilsvarende sanktioner ved regelbrud på ingen måde i vejen. Derfor stod ingen tilsvarende sanktion i historisk perspektiv over for den samfundsmæssige opskrivning af en atlet for hans præstation. Hvad der menes er: Gratifikationen for den »sejrende « kunne holde indtil hans dages ende, og hans materielle eksistens kunne etableres gennem passende investeringer af sejrskapitalen. Som sanktion ved snyderi fandtes der ingen tilsvarende øjeblikkelig eller sågar livslang bandlysning i samfundet.

Hvor anderledes dette blev håndhævet uden for sportssystemet, viser de diakroniske straffe for doping i hestesport, som ikke engang skadede mennesker, men kun hestenes chancelighed (samt totalisatorens væddemål). Også i den tyske ret er det påfaldende, at doping på dette område længe har været strafbart - i dyreværnsloven! Polemisk kunne man udbryde: Lovgiveren ville ikke værne om mennesket. Siden 1998 eksisterer der endelig en udvidelse af lægemiddelsloven, som fremskynder drastiske straffe for gerningsmænd, men stadig ikke for den aktive.

Noget andet at overveje: Også efter endt doping kan sundheden skades. ${ }^{47}$

Højpræstationstræningen ligger under for den samme logik, hvis træner og omgivelser undgår helbredende kontrastyringer. Det er ikke kun skandinavernes »alpehyt- te «, hvor atleter (og familie) »lever« i tætnede huse med kunstig højdeluft for at opnå blod-dopings-effekter. Det er heller ikke det misbrug af Kreatin ${ }^{\circledR}$, som kræver høje præstationer af kroppen, igennem hvilket æggehvidestof i organismen skal nedbrydes, svarende til 10-20 kg muskelmasse pr. dag (et misbrug, der, i parentes bemærket, fører til samme muskulære bivirkninger som anabolika!). Det er konsekvent træning med det mål at opnå høje præstationer hen over en lang konkurrenceperiode. Den langsigtede præstationsevne og »tilstrækkelige « sundhed i tiden efter karrieren spiller i den forbindelse ingen rolle mere.

Også på dette område er DDR med dets foragt for menneskerettigheder gennem den kompromisløse indstilling på udførelsen af et »sportspolitisk højdepunkt « et lærestykke for omgangen med problemet: Alle funktionsgrupper i den østtyske sportsklub,$^{48}$ der var delagtige ifølge forfatterens homologi-model, skulle tjene det samme paradigme. Dette tillod ligefrem sundhedsskader efter forgodtbefindende, også fordi denne variant af sport hældte til selvreference: De ærlige, der pukkede på autonomi blandt sportsfolk og sundhedsbeskyttelse (subjektorienterede læger og trænere), var så farlige for systemet, at de hyppigt blev »fjernet« straks og hemmeligt af det hemmelige politi eller med en længere frist og åbent af »elitesporten« selv. Også i den doping-frie sport er instanser, der sørger for autonomi, altså nødvendige. Sundhedsbeskyttelse af de på mange måder truede elitesportsudøvere skulle derfor også lagges uden for atletens og dennes omgivelsers fulde selvbestemmelse. Autonome instanser skulle også kunne udtale startsforbud. Denne tanke kan synes revolutionær, men er ikke grundlæggende ny boksere skal til lægen, og ringlægen må gribe ind; langrendløbere skal ved højt 
vægttab (dehydrering) afbryde konkurrencen etc. Ordenspolitisk mod er påkrævet for at kunne begrænse sundhedsskader stærkere end tidligere. Ligesom i den tyske rusmiddelslov har menneskets krav på selvrealisering af sine grænser, uanset om der dopes ud fra politisk-samfundsmæssige eller materielt-individuelle motiver. I hvor høj grad den politiske »indikation« for doping var grundlag for DDR's sportspolitik, fremgår af følgende paradoksale unders $\emptyset$ gelsesresultat:

- For at opnå en fordel i det internationale sportssamfund indførte DDR-sportsledelsen regelbrud gennem misbrug af medikamenter, også i fodbold (som i tilfældet med OL i 1976)!

- Den, der ville undfly doping-tvangen for at kæmpe »fair« (eller fordi han eller hun som undtagelsesatlet slet ikke havde brug for doping), blev med undtagelse af to ved navn kendte tilfælde fjernet fra elitesporten - som sikkerhedsrisiko og ikke tilstrækkeligt præstations(»kamp«-)beredt atlet.

- Inden for landets grænser var det fuldstændigt anderledes: I DDR-fodbold gjaldt på nationalt niveau et doping-forbud-for at varne om chanceligheden og holde resultatet åbent. ${ }^{49}$

Tydeligere kan - heller ikke fra et didaktisk perspektiv - meningsløsheden i en almen doping-frigivelse ikke begrundes: Selv det Østtyske sportssystem, der formodentlig var styret $100 \%$ af politisk opportunitet, afslog en sådan frigivelse uden for en planlægning, som man anså for fornuftig, ligesom doping af biologisk endnu ikke »modne« atleter var forbudt af en lang række årsager, og ligesom selvmedicinering sportsretsligt principielt blev sanktioneret med eksklusion. Man bør i denne forbindelse være opmærksom på, at stats-doping-landene var de eneste sportssystemer, som havde et differentieret kendskab til paletten af sundhedsmæssige skader! Birgit Dressel ville som kaderatlet i det tyske forbund for atletik i DDR muligvis ikke være død af doping-følger, fordi symptomerne dér sandsynligvis havde været kendte og kunne være blevet behandlet i en »VS-klinik « som i tilfældet med en DDRvægtløfter, der kollaberede pga. leverkoma.

\section{Noter}

1. Christiane Eisenberg, »English Sports« und deutsche Bürger: Eine Gesellschaftsgeschichte 1800-1939 (Paderborn, 1999). (Sml. også udgaven i »Stadion«, i tryk).

2. Se hertil Günther Wonneberger, »Die Auswirkungen des Leistungssportbeschlusses von 1969 auf den Basketballsport in Leipzig - Erinnerungen eines Zeitzeugen« I: Giselher Spitzer og Harald Braun (red.), Der geteilte deutsche Sport (Köln, 1997), s. 155-158: Her foreligger bevidst udfadning af værdikategorier af den mangeårige rektor for DHfK og Ministeriet for Statssikkerhed-involveret, en hovedansvarlig i det hemmelige DDR-system, der i dag medvirker ved statsligt fi-

nansierede historieprojekter om DDR-sporten. Wolfgang Buss, Sven Güldenpfennig og Arnd Krüger, »Geschichts-, kultur-, sport (politik)- und wissenschafts-theoretische Grundannahmen sowie daraus resultierende Leitfragen für die Forschung « I: Sozial- und Zeitgeschichte des Sports, vol. 13 (1999), heft 1, nærmer sig disse positioner, når de i dag tager sig af kulturhistorisk omorientering: På deres »De-Soziologisierung, DePolitisierung und Re-Kulturalisierung « har ikke mindre end tre videnskabsmænd reageret (i den følgende udgave af Sozial- und Zeitgeschichte des Sports).

3. Om spændvidden af ansatserne, se Christiane Ei- 
senberg, »Sportgeschichte. Eine Dimension der modernen Kulturgeschichte« I: Geschichte und Gesellschaft, vol. 23 (1997); Buss m.fl. (1999), samme sted (anm. 2), og Giselher Spitzer, »Aktuelle Konzepte zur Zeitgeschichte des Sports unter besonderer Berücksichtigung der aktuellen Diskussion im Bereich der Geschichtswissenschaft« I: Sozial- und Zeitgeschichte des Sport, vol. 8 (1994), heft 3.

4. Se i denne forbindelse beretningen om mangfoldigheden i og den relativt tidlige offentliggørelse af tilsvarende litteratur: Gerhard Treutlein, »Zur Auseinandersetzung mit der Dopingproblematik in Frankreich - eine Literaturübersicht « I: Sozialund Zeitgeschichte des Sports, vol. 13 (1999), heft 3 .

5. Begyndende med Brigitte Berendonk, Dopingdokumente. Von der Forschung zum Betrug (Berlin, 1991), og hendes mand, professor Werner W. Franke, f.eks.: Werner Franke, »Funktion und Instrumentalisierung des Sports in der DDR: Pharmakologische Manipulationen (Doping) und die Rolle der Wissenschaft « I: Enquete-Kommission "Aufarbeitung von Geschichte und Folgen der SED-Diktatur in Deutschland, bd. 3 (BadenBaden, 1995); Werner Franke, »Hormondoping als Regierungsprogramm《 I: Grit Hartmann (red.), Goldkinder. Die DDR im Spiegel ihres Spitzensports (Leipzig, 1998 [1997].

6. Se Neue Zürcher Zeitung, 8/8 1998; kritisk diskussion af ansatsen ved Giselher Spitzer og Gerhard Treutlein, »DSB-Mann verharmlost Doping « I: Süddeutsche Zeitung, 27/11 1998. Vedr. tyske lægers doping-mentaliteter, se nedenfor.

7. Se Thuraus berigtigelse i Frankfurter Allgemeine Zeitung, 11/6 1999.

8. Den netop udkomne bog af Andreas Singler og Gerhard Treutlein, Doping im Spitzensport, Sportwissenschaftliche Analysen zur nationalen und internationalen Leistungsentwicklung (Aachen, 2000) fremstiller dette differencieret.

9. Karl-Heinrich Bette og Uwe Schimank, Doping im Hochleistungssport. Anpassung durch Abweichung (Frankfurt am Main, 1995); Karl-Heinrich Bette og Uwe Schimank, »Coping mit Doping: Die Sportverbände im Organisationsstress« I: Sportwissenschaft, vol. 26 (1996), heft 4.

10. Sidst udførligt dokumenteret i »Jahrhundertsport« (Frankfurter Allgemeine Zeitung, 1999).

11. Denne tese ville kunne afprøves gennem retrospektive dataanalyser.
12. Meddelt i 1982 af Hajo Bernett $(\dagger)$ i rammerne for researchen til en fælles udstilling om atletikkens historie ved Institut für Sportwissenschaft der Universität Bonn. I let ændret udgave senere meddelt af DLV-Ehrenpräsident, dr. med. Max Danz, Kassel 1989, der imidlertid ikke ville tage stilling til doping-spørgsmålet.

13. Willi Voet, Massacre à la chaîne. Révélations sur 30 ans de tricheries (Paris, 1999) [Tysk: Gedopt. Der Ex-Festina-Masseur packt aus (Berlin 1999)].

14. Hans Joachim Seppelt og Holger Schück (red.), Anklage: Kinderdoping. Das Erbe des DDRSports (Berlin, 1999).

15. Boris Salomon og Giselher Spitzer, »Warum erhielt der finnische Makkabi-Sprinter Abraham Tokazier 1938 einen Sieg aberkannt?« I: Sozialund Zeitgeschichte des Sports, vol. 13 (1999), heft 3 .

16. Giselher Spitzer, Doping in der DDR. Ein historischer Überblick zu einer konspirativen Praxis. Genese - Verantwortung - Gefahren. Wissenschaftliche Berichte und Materialien des Bundesinstituts für Sportwissenschaft (Köln, 1998); det ændrede 2. oplag er udkommet i marts 2000.

17. Barrie Houlihan, Dying to win. Doping in sport (Strassburg, 1999).

18. Den omvendte virkning af afdæmpning gennem nitroglycrin har ligeledes længe været kendt $\mathrm{i}$ behandlingen af angina pectoris.

19. Dette lader ikke kun kritiske udtalelser fra samtidsvidner til fødselsårgangene 1925-1936, men også en DDR-læges autobiografiske beretninger formode; se Heinz Wuschech, Hexenküche DDR? Ein DDR-Sportarzt packt aus (Berlin, 1998). (Såvidt forfatteren har kunnet udrede det, handler det med Wuschech om en læge, der er medansvarlig for indføringen af anabolika-doping i DDR). I dag befinder der sig også i Bundeswehrs lagre sådanne præparationer, som imidlertid ligesom de højtdoserede selvvirkende atropinsprøjter mod nervegas kun udleveres i forsvarstilfælde. (Kilde: Bundeswehrs uddannelsesplaner).

20. Se John Hoberman, Sterbliche Maschinen. Doping und die Unmenschlichkeit des Hochleistungssports (Aachen, 1994), [Orig.: Mortal Engines: The Science of Performance and the Dehumanization of Sport (New York, 1992)]. Det er trods intensiv efterforskning ikke lykkedes forfatteren, fra informerede tidsvidner at få tilstrækkelige belæg for konventionel doping i årene 1936 til 1940/44 i den tyske letatletik, f.eks. til den se- 
nere Freiburger Schule; enkelte, anonymt frembragte, bekendelser hjælper her ikke videre.

21. Samtale med forfatteren den 23. marts 2000 i Potsdam.

22. Positiv prøve på Clenbuterol hos DLV-højdespringeren E. K. (Frankfurter Allgemeine Zeitung, 12/6 1999). I Frankrig udgjorde Salbutamol® den største andel ved positive kontroller Frankfurter Allgemeine Zeitung og Süddeutsche Zeitung, nov. 1999).

23. Under et historisk aspekt som den første kritiske, netop om lægens rolle: Brigitte Berendonk og Werner Franke opus cit. For den tidligere tid kan man ikke komme uden om Hoberman (1994). Fra et sportsmedicinsk synspunkt foreligger der mange diskussionsbidrag, der udførligt fremlægges og diskuteres i Singler og Treutlin (2000), jf. note 8.

24. Samtale mellem forfatteren og et medlem af svømmelandsholdet, Köln, okt. 1999.

25. Se Giselher Spitzer og Gerhard Treutlin: »Kann Doping effektiver bekämpft werden?« I: Neue Zürcher Zeitung, 2/2 1999.

26. Samtidige diskussioner som den mellem EF's sportsministre og de af disse uafhængige sportsparaplyorganisationer kan næppe fastlægges på noget andet område.

27. De juridiske problemer bliver genoptaget og diskuteret yderligere nedenfor; her skal kun nævnes en juridisk doktorafhandling: Martin Sievers, Die zivilrechtliche Haftung des Sportlers wegen Dopings (Clausthal-Zellerfeld, 1996); også i dagspressen kan man stifte bekendtskab med ikkesportsjuristers intensive principdiskussioner. Sml. om svømning også bidragene i Seppelt opus (1999).

28. Giselher Spitzer: »Spätschaden durch Doping bei Sportlern der ehemaligen DDR «I: Christian Müller-Platz (red.), Leistungsmanipulation: eine Gefahr für unsere Sportler. Wissenschaftliche Berichte und Materialien des Bundesinstituts für Sportswissenschaft, bd.12 (Köln, 1999). Se også enkelttilfælde, hvor tidligere kvindelige sportsudøvere træder ud af anonymiteten: »Blaue Bohnen von Dr. Mabuse « I: Der Spiegel, 28/2 2000.

29. Den tidligere $1 \varnothing b s l æ g e$ ved Tour de France, J.-P. de Mondenard, kom allerede i sit første udkast ind på aspektet »Drogues et Dopages« (Quel corps? Editions Chiron, 1987).

30. I et diplomarbejde, som forfatteren har været vejleder for, om sundheds- og selvkoncept hos mandlige bodybuildere (ekstremgruppe) udvises der allerede i prætest-fasen, før interview-ledetråden afprøves, mange afvigelser fra normal adfærd. En af sportsudøverne er som følge heraf i mellemtiden gået i terapi på en »Landesklinik«. Psykogene forandringer gennem ekstremt $h ø j$ anabolika-anvendelse synes altså at kunne bevises.

31. Se den udmærkede interdisciplinære problemanalyse af Matthias Kamber, Primus Mullis og Martial Saugy, »EPO - vom Medikament zur perfekten Wunderwaffe im Sport. Zum Stand der Forschung nach einem Nachweisverfahren von Doping mit Erythropoietin« I: Neue Zürcher Zeitung, 18/3 2000.

32. Samtale med forfatteren den 23. marts $2000 \mathrm{i}$ Potsdam.

33. Hajo Bernett, Körperkultur und Sport in der DDR (Schorndorf, 1994). En litteraturberetning særligt om den ældre litteratur fra vesttysk sportsvidenskab og den ældre »Deutschlandforschung « overstiger dette bidrags pladsmuligheder. Som almen litteratur om professionel DDR-elitesport skal enkelte titler fremhæves: Kortfattede overblik over den nyeste forskningsstand: Anke Delow, Giselher Spitzer m.fl., »Das Leistungssystem der DDR in der zweiten Hälfte der achtziger Jahre und im Prozess der Wende« I: Bundesinstitut für Sportwissenschaft - Jahrbuch 1998 (Schorndorf, 1999). Giselher Spitzer, »Zur Kontrolle des Leistungssports sowie der Sportwissenschaft durch das Ministerium für Staatssicherheit der eh. DDR« I: Sportliche Leistung im Wandel. Schriften der Deutschen Vereinigung für Sportwissenschaft, bd. 94 (Hamburg, 1998). Yderligere kritisk og pointeret fremstillende litteratur kan anbefales til erhvervelsen af et overblik: Giselher Spitzer, Hans Joachim Teichler og Klaus Reinartz, Schlüsseldokumente zum DDR-Sport. Ein sporthistorischer Überblick in Originalquellen (Aachen, 1998). Grit Hartmann (red.), Goldkinder. Die DDR im Spiegel ihres Spitzensports (Leipzig, 1998 [1997]). Eksakt i den kvantitative rekonstruktion, men relativt uskarp i de tre spørgsmål om dopingens rolle, det hemmelige politi og menneskerettighederne i sporten er derimod bidragene fra den første af de to redaktører i: Hans Joachim Teichler og Klaus Reinartz (red.), Das Leistungssportsystem der DDR in den 80er Jahren und im Prozess der Wende (Schorndorf, 1999).

34. Gudrun Fröhner og Giselher Spitzer, Kammerretten i Berlins dom af 12. februar 1999, AZ 9 U 4797/98, her s. 9 og s. 12. 
35. Se: Giselher Spitzer, »Wie offen war der Verhandlungspartner NOK der DDR? Zur Rolle des MfS in den Beziehungen zum Sport in der Bundesrepublik« I: Ommo Grupe (red.), Deutschland Einblicke. Aspekte olympischer Erziehung (Schorndorf, 1999).

36. Giselher Spitzer, »Die Akten des Ministeriums für Staatssicherheit als »Reserve-Archiv« des DDR-Sports? Quellenkritische und methodologische Bemerkungen « I: Giselher Spitzer og Harald Braun (red.), Der geteilte deutsche Sport (Köln, 1997).

37. Enkeltbeviser undgås, se dertil Spitzer (1998), jf. note 16 .

38. Interview med $\varnothing$ jenvidne, dr.med. D. B. i august 1998; Berlin.

39. Chefen for det centrale bedømmelsesudvalg har (under det aspekt, at mange doping-midler ikke engang klinisk var tilladt til brug på mennesker) den fortjeneste at have presset på med lovlig adfærd til trods for sportsministerens modstand. Da han også måtte gøre tjeneste som IM for Ministeriet for Statssikkerhed, kom det ikke til et gennembrud.

40. På lignende måde lærte de at tage imod sportsretsligt forbudte pengebetalinger fra staten.

41. Hartmut Riedel, Zur Wirkung anaboler Steroide auf die sportliche Leistungsentwicklung in den leichtathletischen Sprungdisziplinen (Bad Saarow, 1986). Ud fra analysen plæderer han for en overholdelse af 1-g-grænsen, se s. 206. (Dette tyder efter min mening på en bevidsthed om den enorme trussel). Se også aftrykket i Franke, (1995), s. 1121.
42. »Funktionelle eller morfologiske leverforstyrrelser « med den interessante angivelse $» 0-1 \%$ « bliver ligeledes ført tilbage hertil; se Franke (1995), s. 1121 og s. 1134.

43. Se forordet til 2. oplag i Spitzer (1998), jf. note 16.

44. Ifølge Videotext ARD og B1 fra 12. april og 21. juni 1999.

45. Se dertil de udførlige fremstillinger i Singler og Treutlein (2000), jf. note 8.

46. Under ledelse af Karl-Heinrich Bette, Gerhard Treutlein og forfatteren.

47. Hvad angår de i 1998 af forfatteren benævnte Beratungsleistungen (rådgivningsydelser) er noget sket: Den fordrede offer-beskyttelse befinder sig ligesom en gerningsmand-offer-udligning på stadiet af parlamentariske initiativer. Der skal også henvises til »die Doping-Opfer-Hilfe e.V.« (Luisenstraße 23; 69469 Weinheim). Vurderingen, at det åbenbart (selv ved bevisligt ringe dosering) kommer til beskadigelse af de samlede arveanlæg hos dopede sportsfolk og dermed til misdannelser hos børnene af denne risikogruppe, førte ligeledes til revisioner.

48. Se hertil Anke Delows fremstilling, »Leistungssport und Ideologie - die Vorbereitung der Olympischen Spiele in einem DDR-Sportclub « I: Sozial- und Zeitgeschichte des Sports, vol. 11 (1997), heft 2.

49. Giselher Spitzer, »Spitzenfußball in der DDR. Kontinuitäten und Entwicklungsbrüche zwischen Selbstbestimmung und (innen-) politischer Funktionalisierung « I: W. Ludwig Tegelbeckers, Quo vadis Fußball? Vom Spielprozess zum Marktprodukt (Göttingen, 2000). 